\title{
A RE-EVALUATION OF THE TRANSLATION OF THE HEBREW CONCEPT חסד INTO LOMWE: A COGNITIVE FRAMES OF REFERENCE MODEL APPROACH
}

\author{
Justino Alfredo \\ Old and New Testament \\ Stellenbosch University
}

\begin{abstract}
This article demonstrates how the Cognitive Frames of Reference model can be applied to translate the Hebrew concept problem with the translation of practical procedure(s) used in the current Lomwe Bible translation project are examined in an attempt to find a suitable equivalent term (word or phrase) for Tor.
\end{abstract}

Key Words: Cognitive Frames of Reference; Lomwe Bible Translation;

Catholic Version; Protestant Version

\section{Introduction}

In the article entitled, Translating Biblical Words: A Case Study of the Hebrew Word חסד. I presented a theoretical model of Cognitive Frames of Reference (CFR) which uses different frames (i.e. lexical, textual, socio-cultural, communicational and organizational) as a conceptual framework for exploring contextual domains. The model shows that the different frames of reference guide the translation of חסד in such a way that the intended meaning this word evoked in the minds of biblical hearers may be clearly evoked, at least to the extent possible, in the minds of a contemporary audience.

Therefore in this discussion I will demonstrate how the CFR model can be applied in translating the Hebrew word חסד into Lomwe. But before doing this, I shall first present the problem with the translation of חסד into Lomwe. Thereafter, I will discuss some of the practical procedures used in the current Lomwe Bible translation project in an attempt to find a suitable equivalent term (word or phrase) for חסד.

\section{Problem with the Translation of חסד into Lomwe}

Although the word osivela is identified as a suitable term, another word woororomeleya (which literarily means faithful in a domestic context) ${ }^{2}$ has also been considered in the

This article is available in Scriptura, Vol. 109, 2012.

In the Semantic Dictionary of Biblical Hebrew (SDBH), the word faithful (which has been registered for חסד with different glosses) means to act in accordance with the attitude of loyalty, faithfulness, kindness, devotion and love. What these terms simply tell us is that, when translated into English, חסד may be rendered as one of 
translation of חסד. For example, in the published Lomwe translation of Ruth חסד is rendered as osivela waya woororomeleya (his/her faithful love). This expression was coined by the Lomwe translators and is used in a narrative context, while osivela is used exclusively in a poetic context. The current translators of the Old Testament into Lomwe have suggested therefore that חסד be translated as either osivela or osivela combined with woororomeleya.

However, this decision by the current translators appears problematic because in the 1930 Lomwe translation of the Psalms, another word ikharari $^{3}$ is used exclusively for חסד. Besides the fact that ikharari is used in the older translation, the concept is also in use among the agrarian Lomwe people (cf. Assane 2002). From this background information, the following questions arise: Why have the present Lomwe translators of the Old Testament moved away from the rendering of חסד as ikharari to osivela or osivela combined with woororomeleya, and what are the implications of this shift when viewed from the Lomwe's socio-cultural context? What practical procedure(s) of research and translation did the Lomwe translators apply? These questions invite us to examine the current translation of חסד into Lomwe in an attempt to find a suitable equivalent term or word.

\section{Practical Procedure(s) Applied in Lomwe Bible Translation}

Bible translation is a rather complex process which involves the vagaries of language and cross-cultural communication further complicated by the need to recreate (or re-express) meaning across distant and disparate cultures and language families. Therefore, it is imperative that every Bible translation project has a set of working procedure(s) that guides and drives it as part of its organizational frames. The present Lomwe Bible translation project for example is composed of two translators and an exegete. The two translators are Lomwe mother-tongue speakers while the exegete is a missionary who has lived among the Lomwe since $1986 .{ }^{4}$ In the next paragraph, I will present a summary of the principal operating procedures that guide the Lomwe Bible translators in their daily practice with special reference to their translation of the Old Testament.

these five glosses, depending on the context. However, this does not truly convey to us the meaning of the biblical concept.

3 After a thorough search and consultation with the SBM, I can confirm safely here that to my knowledge no translation minutes or records can be found that document the decision of the older translation of 1930 to render חסד as ikharari.

4 It should be mentioned here that the mother-tongue Lomwe translators have relatively little theological training. This of course is not unique to the Lomwe translators as similar cases can also be found in the northern part of Mozambique. According to Floor (2005:n.p), the following factors contributed to this state of affairs: (i) the slow start of the Catholic and Protestant churches in the country; (ii) the legacy of colonialism, the policies of which did not promote the national languages and did not provide secondary education for all; and (iii) the devastation of two subsequent civil wars, which ended only in October 1992. Floor also remarks that linguistics and translation theory have made great positive strides during the past 20 years, the most marked development being the progress of cognitive linguistics, pragmatics, discourse studies, and sociolinguistics - presumably this also means the acquisition of more linguistic skills on the part of all translators. 
Source used

Since the Lomwe translators are not familiar with Biblical Hebrew ${ }^{5}$ they follow the socalled Base-Models method of translation which is essentially a comparative procedure. In the method a relatively literal Portuguese Bible version (in this case the Almeida version) is employed as the 'base' to give translators some idea of the actual linguistic form of the original text. This is then compared with a selected number of freer Portuguese versions such as A Boa Nova (Good News Bible) which illustrates how the literal base text may be modified in various ways to express more clearly and in a more natural style the intended meaning of the biblical message in a given language. When working with these different versions, translators also use the Roman Catholic translation Bibiliya Nsu na Muluku (first edition). ${ }^{6}$ This version helps the translators to access the biblical message already restructured or pre-digested in the lexical and grammatical forms of the Lomwe language. ${ }^{7}$

As regards the translation of חסד as osivela (love) the translators admit that their decision is indeed problematic. The acknowledgement came after the translators themselves noted that the Catholic version translated the word 'love' (between God and people as well as between people) as okhwela instead of osivela. The term osivela is used in the Protestant New Testament translation of 1930 which is currently under revision (again for both the relationships between God and people, and between people). The disagreement over the translation of the word 'love' ensues because Lomwe lacks a specific term for this particular English word. Whereas osivela connotes love in general okhwela in ordinary conversation may have a sexual connotation (i.e. affection for the opposite sex). Not one of these terms is therefore specific enough to express the idea of love between people and between God and His people.

As part of the revision of the Protestant version a debate in church communities resulted in the decision to substitute the word osivela with okhwela - in spite of its possible sexual connotation - in contexts where the love between God and His people is expressed. Furthermore, the Protestant translators decided to retain the word osivela for the 'love' between people, and reserve the word okhwela for the relationship between God and His people. ${ }^{8}$ For instance, in the Gospel of John 3:16, God's love for humanity is translated

5 In November 2008, the SBM organized a three-week Lusophone workshop. The aim was to introduce the Hebrew language to translators and to warn them of some dangers of basing translations on a secondary source (that is, on the Portuguese Bible Version João Ferreira de Almeida) which is sacred to translators in the other four Portuguese-speaking African countries: Angola, Cape Verde, Guinea-Bissau, and São Tomé and Principe.

6 Historically, Lomwe was one of the largest language groups in Africa without a complete translation of the Bible though translations of the Protestant New Testament and the Psalms were published jointly in 1930. The first edition of a complete Lomwe Catholic Bible Bibiliya Nsu na Muluku was published in 2004. After some revisions, the second edition was published in 2008. It is important to mention here that although the Roman Catholic Bible version has been finalized it is not yet available to most Lomwe readers because of its exorbitant price.

7 The Catholic Bible Bibiliya Nsu na Muluku is the only Bantu language version that the Lomwe translators have at their disposal but they could have increased the effectiveness of their methodology if they had access to translations from other related languages.

8 Although this distinction in usage is made by the Protestant translators, the decision can be faulted since the word okhwela has a sexual connotation in some contexts. If okhwela would be retained in the translation, a glossary entry should be added to explain its limited usage in the translation which would indicate that it is 
as okhwela. Similarly, the word love (for one another) is translated as okhwela (1 John 4:8). Since osivela refers to love in general it fails to convey the specific meaning of חסד. Hence, the translators pointed out that the use of osivela, the phrasal expression of osivela waya woororomeleya (literally, his/her faithful love) was invented to specify the intended area of meaning more precisely (by combining osivela with woororomeleya).

\section{Language used}

Since the translators pointed out that no prior research had been conducted on חסד, the following questions arise: Which terminology did the translators and the exegete then adopt? Was it that of the Protestants or that of the Catholics or did they adopt their own independent approach to the translation of this term?

The Lomwe translators and the exegete indicated that they used neither the language of the Protestants nor that of the Catholics in the translation of חסד. According to the Lomwe exegete, the translators did not use the terminology by either of the two existing versions, in order to avoid the accusation of bias. However, the translators indicated that they value the opinion of the Lomwe elders during consultations on problematic terms because they obtained important information from the language of this group. Not surprisingly, the elderly play an important role in translation, as Aroga Bessong points out:

In Africa one cannot overemphasize the importance of the elderly in maintaining and perpetuating the cultural heritage in general and the language in particular... Youths, even adults, can feel that their linguistic competence is inadequate, limited compared to that of the elderly... The focus on the language of 25-35 year olds needs to be reconsidered in the African context (cited in Wilt 2007:120-121).

Although the intended audience of the Old Testament translation of Lomwe has been identified, there are some challenges which undermine the usage of mother tongues because Portuguese remains the language of instruction today:

The fact that less than 25\% of Mozambicans are functionally competent in European Portuguese, has prompted many, such as Lopes to question whether Mozambique is a Lusophone country in any meaningful sense of the words. For him, and others, the country is Bantuphone through and through (Yorke 2004:67).

For this reason, there is a sustained call for the use of the mother tongue as the primary medium of instruction, at least at the elementary or primary school level. According to Kitoko-Nsiku (2007:261), the revitalisation of Bantu languages in Mozambique would mean that the endangered languages would be the object of a newfound vigour, both in terms of their usage and promotion as well as study. For example, as part of its bilingual education program, leaders of FRELIMO, ${ }^{9}$ the current ruling party in Mozambique, believe that all Bantu languages should be restored ${ }^{10}$ to their earlier prestige and become real

exclusively used as a reference for the love between God and His people, a context in which its sexual connotation will not ordinarily come up in the minds of the Lomwe readers.

9 Frelimo is the Frente de Libertação de Moçambique, i.e. the Front for the Liberation of Mozambique.

10 For a discussion of the Bilingual Education Programme (Pebimo) set up to restore Bantu languages in Mozambique, see Kitoko-Nsiku (2007). 
vehicles for education in each local area of the country where a large number of mother tongue speakers live. Kitoko-Nsiku (2007:262) further argues that the revitalisation of Bantu languages in Mozambique should be done in such a way that widely spoken languages such as Xichangana and Emakhuwa are not imposed on lesser-spoken Bantu languages as was the case with Kiswahili in Tanzania and Kenya.

\section{Another Technique used}

Another technique used during the translation process is the application of the four-stage 'method'11 which involves analysis, transference, restructuring and comparison. It should be mentioned here that the Lomwe exegete co-ordinates these four basic steps. The first is the stage of analysis where the text-drafter carefully studies the different versions at hand together with a selection of recommended commentaries and resource texts such as Bible dictionaries. The goal is to establish the central meaning and function of a given passage of Scriptures in its surrounding context of use in order to convey the intended meaning in the target language. Second, this central corpus of sense and significance is then transferredfirst, into the appropriate thought forms or conceptual categories of the Lomwe and subsequently, into actual utterance units, discourse patterns, and rhetorical features that are natural in the Lomwe language and culture.

Third, the foundational text is restructured into a form that is compatible with Lomwe language style for it to be functionally equivalent to the biblical text in as many respects as possible. Afterwards, a review committee of church leaders is invited to scrutinize and critique a given pericope to ensure that it serves essentially the same primary communication purpose as does the original message in its given scriptural setting, both near (the immediate context) and far (the Bible as a whole).

Finally, the draft translation is compared with the original text or at least two of the versions that were referred to above that is, the Portuguese Almeida version and the Lomwe Catholic version. At this stage, the translation consultant (who regularly visits the project) is invited to assess the final product. The aim of this step is twofold: (i) to ensure that no part of the basic biblical meaning is lost, distorted or rendered incorrectly in the translation, and (ii) to ensure that the meaning is also conveyed clearly and naturally in contemporary Lomwe idiom.

Subsequently, I will demonstrate how the CFR model can be applied to the translation of חסד into Lomwe. This model can help us bridge the cognitive gap that exists between the socio-cultural worlds of the biblical audience (Israelites) and the target audience (Lomwe). In addition, it should be mentioned here that in order to bridge more closely the cognitive gap between these two groups, fieldwork was conducted as part of the CFR model to ease translation in terms of the target audience. ${ }^{12}$ One of the aims of the fieldwork was to read aloud to the Lomwe people the three selected passages from the translation of the book of Ruth where the word חסד occurs in order to determine whether those listening

\footnotetext{
11 While the first three steps of this method can be traced back to Nida and Taber's (1969) work entitled, The Theory and Practice of Translation (referred to as TAPOT), Wendland (1987:77) has added the last.

12 For the findings from this fieldwork, see (Alfredo 2010:185).
} 
to the translation understood it clearly and correctly. As part of the overall approach, two different versions of the Lomwe Bible, namely the Catholic version (CV) and Protestant version (PV) were read aloud. The reading was done without disclosing the two versions to the readers.

At this point, it will be helpful to consider some ways in which the CFR model can be applied to translating of חסד into Lomwe.

\section{Application of CFR to the Translation of חס in Ruth ${ }^{13}$}

In keeping with the focus on the selected passages of Ruth in which חסד appears, I wish to propose a rendering that uses certain literary features of the Lomwe as a means of preserving the textual meaning of חסד.

Translation and comment ${ }^{14}$ on Ruth 1:8

\begin{tabular}{|c|c|c|}
\hline Hebrew text & Greek text & $\begin{array}{l}\text { Lomwe }^{15} \text { text with English } \\
\text { back-translation }\end{array}$ \\
\hline 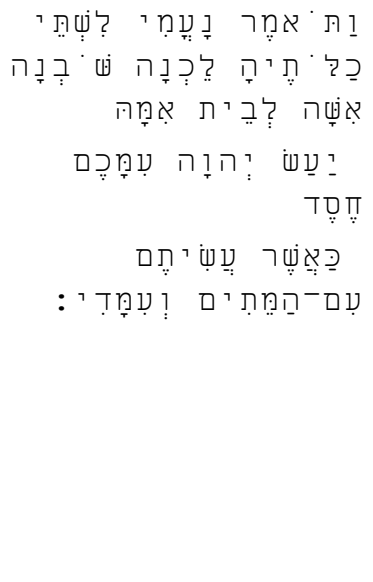 & 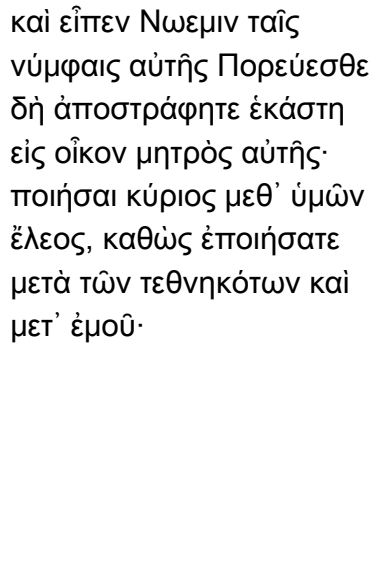 & $\begin{array}{l}\text { Nawomi aahi wa yaawo: Mmoha } \\
\text { ni mmoha akookeleke wa } \\
\text { amannya; nave Apwiya } \\
\text { ewooniheryekeeni osivela waya } \\
\text { woororomeleya [ דס] ntoko tho } \\
\text { mwaawooniheryaanyu asiiyanyu } \\
\text { akhwile ni miyo tho. } \\
\text { Naomi said to them [Ruth and } \\
\text { Orpah]: "Each of you, go back to } \\
\text { your mother's [house]; may the } \\
\text { Lord show [דס] as you did to } \\
\text { your late husband and me." }\end{array}$ \\
\hline
\end{tabular}

Table 1: Ruth 1:8 in Hebrew, Greek and Lomwe texts

In the passage above, Naomi wishes that Yahweh would show חסד to her two daughters-inlaw, Ruth and Orpah as they have shown חסד to her and their late husbands. Naomi then tells her two daughters-in-law to go back to their mother's house. ${ }^{16}$ This suggestion may seem unexpected given that in most cases reference would be to the father's house. ${ }^{17}$

\footnotetext{
13 For the reasons for choosing the Book of Ruth, see (Alfredo 2010:3).

14 By 'comment,' I mean the usage of the different frames of reference. Here I also engage with the translation itself as part of the interpretation process.

15 The Lomwe translations used in this table and below are from SBM (2008).

16 Apart from the occurrence of this phrase in the Ruth story, it is also found in the Rebekah story (Gen. 24:28) and in the Songs of songs 3:4 and 8:2 (cf. also Prov. 9:1; 14:1; 31:10-31). The inter-textual relationship with reference to the mother's house highlights the role of a woman in the family.

17 Cf. Genesis 24:38; 38:11; Numbers 30:16; Deuteronomy 22:21; Levticus 22:13; and Judges 19:2,3.
} 
However, given the influence that women had on affairs within the household (cf. Meyers 1991:50), it is not unusual for Naomi to refer to a mother's house. According to Meyers, this term draws us into the household setting that circumscribed the life activities of both Israelite women and men. Within that setting, "women's voices were heard, their presence was valuable and valued, and their deeds and words had a profound influence on others" (Meyers 1991:50, emphasis added).

The aforementioned influence went beyond the family household. ${ }^{18}$ Women participated in marriage arrangements for their children with some economic if not political implications. Arranging a marriage normally involved some perspicacity and diplomacy as part of the negotiation process. The negotiation process included the elders as important members of the community who acted in a facilitating capacity. A man could acquire a wife through personal purchase, which was more in the nature of compensation to the family for the loss of a valued member. In instances where payment was not possible, certain services could be provided to the family for a certain period before a man acquired a woman as his wife (e.g. Jacob who served Laban for 14 years for Rachel and Leah). ${ }^{19}$ After the conclusion of such a process (i.e. purchasing/rendering of services), the marriage took place and the woman left her father's house to live with her husband.

The role of women in a marriage relationship was very diverse in the sense that they performed a variety of essential tasks. In addition to being mothers with the obvious task of nursing and raising children, women were also involved in food production and processing which indicates their control over the daily affairs of the family. Hence, the domestic scene was the realm of women where they had much impact on the welfare of the family. ${ }^{20}$ Ruth working in the fields is a good example of how women in an agrarian society contributed to the wellbeing of their families. It could be argued that the notion of caring for the family was closely linked to the idea of showing חסד particularly by a wife to her husband. Such an assumption also finds support in the story of Ruth in which Naomi stressed the that Ruth and Orpah had shown not only to her but also to their late husbands. Naomi's statement is a clear indication that in ancient Israel an act of חסד entailed more than just an expression of love within a marriage; it also manifested in the various roles of women within such a relationship. Moreover, it bears witness to the idea that the two daughters-inlaw conducted themselves well while in their husband's houses as far as the fulfilment of the abovementioned roles is concerned.

Given that the Lomwe society is matriarchal its marriage system differs from that of ancient Israel which was patrilocal because a woman left her father's house to live with her husband's family - Lomwe custom obliges the husband to leave his family and join his wife's family, where he will be under the authority of the parents-in-law. Men are expected to be dutiful to their in-laws at least during the early stages of marriage. If the man fails to

18 For example, apart from participating in marriage arrangements, women also acted as prophets (cf. Miriam in Exod. 15:20-21 and Deborah in Judg. 4:4).

19 See Genesis 29:15-30.

20 Although women took on various roles within the family, men were in no way marginalised as far as family issues were concerned. As head of the household, a man still had to protect his family and provide guidance on family related matters. 
impress the in-laws and proves himself unworthy, his parents-in-law can send him back home to his parents and annul the marriage.

If a married man dies without any close relatives (i.e. a brother or a cousin) to replace him officially in his widow's family, his family has an obligation to pay the widow a token and accompany her to her relatives. With that, the widow becomes eligible to re-marry and she gains the support of the community. Despite the differences in the two marriage systems, there is a similarity in the position of widows in the two societies. With the death of their husbands Naomi advised both Ruth and Orpah to return to their mother's houses. ${ }^{21}$ This case is comparable to the Lomwe matrilineal practice.

Having discussed the socio-cultural milieus in which both marriage systems operate, it is important to consider at this point the implication of rendering woororomeleya (his or her faithful love) in Lomwe. The Lomwe translators have chosen this phrase as the most suitable term for חסד because it is used within a marriage relationship in Ruth 1:8. Although one of the contexts in which חסד is used is the marriage relationship, the structure of the sentence (particularly the second part of it) could also clarify the usage of the term. Ruth 1:8b refers to Yahweh's חסד to the daughters-in-law of Naomi. Before mentioning the חסד shown by Ruth and Orpah to their husbands, Naomi wished that Yahweh would show his חסד to her two daughters-in-law who were now widows. Naomi's request implies the restoration of the former position of Ruth and Orpah as wives.

According to Meyers (1978:98), wives in ancient Israel had honour, prestige, selfesteem, and respect in the family by virtue of their position and roles. The wish here for Yahweh to show his חסד to Ruth and Orpah does not only imply restoration but also protection since in ancient Israel widows, like orphans and the poor, were vulnerable to exploitation. Since these groups had no rights and were treated as social outcasts, they needed protection (cf. Fensham 1962:137). One could argue that Ruth and Orpah faced a similar situation since their husbands had died. Hence, Naomi's request that Yahweh should show חסד to them could imply the restoration of their former position to prevent them from suffering the fate of so many other widows in ancient Israel. Given the precarious situation of widows, the call for Yahweh to protect Ruth and Orpah comes as no surprise. Once their situation was restored (being married again, having honour, prestige, self-esteem and respect) they would also have the necessary protection from their husbands. Until such a time, Yahweh should act as their protector and provider (request for divine חס).

Up to this point, it is clear that in Ruth 1:8, חסד implies action. Just as Ruth and Orpah showed חסד to their late husbands (action), Yahweh would show חסד tom tacts restoration and protection). Since חסד signifies action, one could ask whether osivela waya woororomeleya captures this particular meaning of the word in Ruth 1:8. Although the word osivela has been combined with woororomeleya to capture the idea of love, it fails to highlight the notion of action associated with חסד in this verse. Given this semantic failure of osivela waya woororomeleya, the word ikharari used with the associated verb omorela

21 The LXX recognises this ancient custom with its use of the phrase oîkov $\mu$ про̀ ('mother's house'). 
should be considered a more suitable translation of חסד because it underscores the idea of action. $^{22}$

It should be mentioned that in addition to the CV's use of ikharari in Ruth 1:8, the empirical results confirm the people's preference for this term. Based on this evidence, one could therefore argue that ikharari seems to be a more appropriate rendering because it emphasises the aspect of action which involves care. ${ }^{23}$ This idea resonates with the understanding of the Lomwe people which is to show that חסד involves action that focuses on the wellbeing of the one to whom חסד is shown. Given this exposition, one can argue that osivela waya woororomeleya is not an appropriate translation of חסד because in Lomwe 'to love someone' implies doing something as an act of solidarity (notion of action: ikharari $)^{24}$. This point is evident also in Ruth 2:20:

Translation and comment on Ruth 2:20

\begin{tabular}{|c|c|c|}
\hline Hebrew text & Greek text $^{25}$ & $\begin{array}{l}\text { Lomwe text with English back- } \\
\text { translation }\end{array}$ \\
\hline 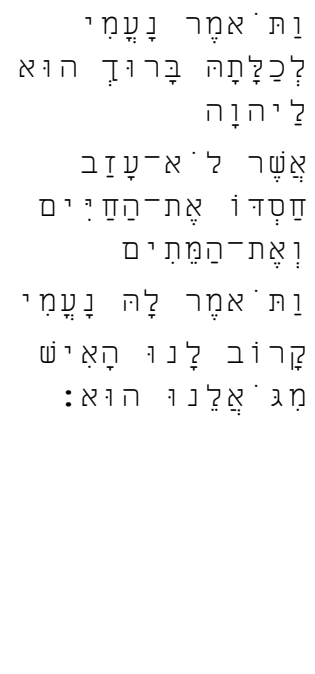 & 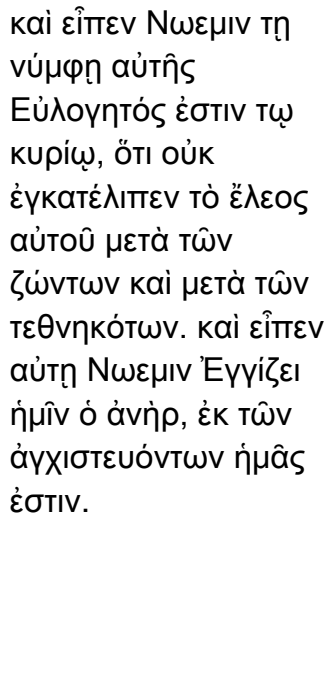 & $\begin{array}{l}\text { Nawomi aamwaakhula: "Apwiya } \\
\text { yaawo ahinahiya osivela waya } \\
\text { woororomeleya [ Toח] wa achu akumi, } \\
\text { nari wa achu ookhwa, emureelihe } \\
\text { Powase". Aamuleela tho, wii: } \\
\text { "Mulopwana yoowo mmusi ahu, } \\
\text { mmoha a yaawo oophwanela } \\
\text { onthokororya". } \\
\text { Naomi answered: "[May] the Lord who } \\
\text { does not abandon his [דס] to the } \\
\text { living and the dead, bless Boaz". She } \\
\text { then told her [Ruth]: "That man is one } \\
\text { of our relatives, the one who has the } \\
\text { responsibility of caring for us". }\end{array}$ \\
\hline
\end{tabular}

Table 2: Ruth 2:10 in Hebrew, Greek and Lomwe texts

22 Although the word ikharari is a noun, it implies action as song 166 from Foster's (2008:189) collection among the Lomwe people illustrates: Muthiyana ahiloca, Mukimorele ikharari, Mwanaka ori ophariwe ti nsololo, "A woman says show me ikharari [pity], my child is possessed by an evil spirit" (my translation).

23 For example Genesis 47:29 reads: Mwaakhwelaka okimorela ikharari, mukuhe ntata nanyu vamweconi vaka, nave mulipele moosivela wi munamweerano mweeparipari yooveka ak (SBM 1999), i.e. "If you wish to show ikharari [care], put your hand under my thigh and swear that you will do my request" (my translation). Similarly, in 1 Kings 20:31 we read: Vaavaa anamuteko a Penehatate yaamuleela yoowo, eriki: Tiwi, nohiiwa wi mamwene a alsarayeli anaamorela achu ikharari (SBM 1999), "Then his workers said to him [BenHadad]: "We have heard that the kings of Israel do ikharari [care] about people"” (my translation).

24 Since the Lomwe and Makhuwa are related in terms of their languages and cultures, it is interesting to note that the Makhuwa translators have opted for the word ikharari in Ruth 1:8.

25 Although the Greek text does not also play any significant role in the discussion of 2:20, it is shown in the table in order to present the text consistently. 
In the passage above, it is not clear whether Boaz or Yahweh is the subject of the action. However, I have argued elsewhere ${ }^{26}$ that through this deliberate ambiguity the reader becomes fully aware of the fact that Boaz, by acting on behalf of Yahweh when he allowed Ruth to glean in his field, becomes the subject in this verse. Showing such hospitality was required of the people of God throughout the Old Testament as a legal obligation stipulated by custom and the Law (cf. Lev. 19:9-10; 23:22; Deut. 24:19). The moral obligation was based on family values, which fostered solidarity among members of the household. This solidarity manifested itself in the protection and care that members showed to one another. Of particular importance in this regard was the role of the 'kinsman-redeemer' (go'el), who had the obligation to 'redeem' that which was lost through purchase, to avenge the death of kinsmen, and should he happen to be the closest relative of a deceased male of childbearing age, to marry his widow (in what was known as the levirate marriage).

The Deuteronomic law code underpinning the custom of levirate marriage allowed for an element of choice (see Deut. 25:5-10). The brother of the dead man could choose not to fulfil his responsibilities to his dead brother and the widow. For example, the nearest kinsman in the story of Ruth refused to assume his responsibility (4:6). However, acting as Ruth's kinsman, Boaz decided to redeem Elimelech's inheritance and his family line through levirate marriage (cf. also Gen 38). Ruth's marriage to Boaz brought support and hope to Naomi and the (re)assurance that Yahweh did not cease to show his חסד the living and the dead. It was through Boaz that Yahweh's חסד to both Naomi and Ruth was fulfilled. Hence, Boaz's role highlights the significance of the individual's obligation toward and communication with his/her fellow Israelites as the communal "people of God'. ${ }^{27}$

Since the Lomwe society is agrarian, the people practice mutual assistance by exchanging goods and services as part of their survival strategy. For example, Assane (2002:24) points out that mpuha is one of the popular labour sharing devices whereby Lomwe families assist one another to plough each other's fields in exchange for meals or beer brewed by women. This system of solidarity provides sustenance for families particularly in times of crisis. Another system of solidarity practiced by Lomwe Christians is called ikharari (cf. Assane 2002:47). This system provides support; for instance, if a person is sick, a member of the church could help to perform the core household chores until the person recovers. During this period, relationships are established and strengthened. As is the case in the Lomwe society, members of a household in ancient Israel had the obligation to care for each other.

Having established the analogous socio-cultural contexts of both groups (i.e. the Lomwe and Israelites), it is now time to focus on the rendering of חסד as osivela waya

\footnotetext{
26 Alfredo (2010).

27 The concept of Israel as the 'people of God' is also linked with the concept of Yahweh as the God of Israel's 'fathers' or 'Patriarchs' (i.e. Abraham, Isaac and Jacob). This concept of Israel as the 'people of God' is founded upon the covenant which Yahweh made with the Patriarchs, as well as the covenant he made with Israel via Moses. The Israelites can legitimately be regarded as the 'people of God' based upon their acceptance of Yahweh's covenant. For Usue (2006:209), the Mosaic covenant provided certain ways in which other nations, as well as aliens or foreigners such as Ruth could also be included in the covenant through marriage and thereby become by extension 'people of God'.
} 
woororomeleya in Ruth 2:20. According to Lomwe translators, this phrase was chosen as the most suitable translation for חסד in this particular verse because it highlights the everlasting חסד of God. Although Yahweh is the main subject of the story of Ruth, Boaz functions as the subject in this particular passage. Boaz becomes the subject when one reads the second part of the passage in which Naomi reveals the identity of the field owner. As the subject, Boaz provides care and support for both Ruth and Naomi. The action or behaviour of Boaz should be rendered with the same word used in 1:8, viz. ikharari, because it also emphasises care and support as important aspects of the socio-cultural situation depicted in 2:20. Since Boaz's חסד to Ruth and Naomi accentuates care and support, ikharari becomes the most appropriate rendering of חסד 2:20

I will now turn to the third occurrence of חסד in the book of Ruth, that is in 3:10.

Translation and comment on Ruth 3:10

\begin{tabular}{|c|c|c|}
\hline Hebrew text & Greek text ${ }^{29}$ & $\begin{array}{l}\text { Lomwe text with English back- } \\
\text { translation }\end{array}$ \\
\hline 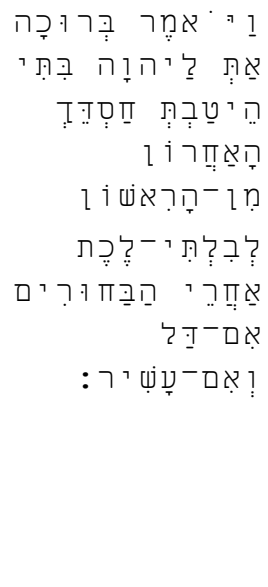 & 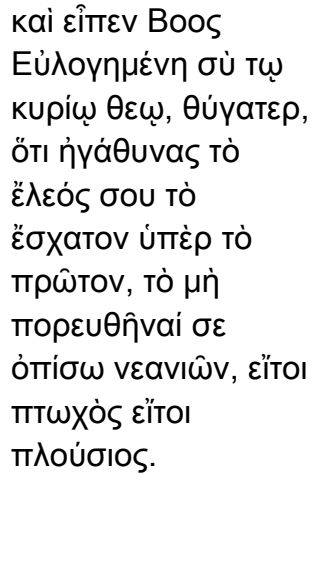 & $\begin{array}{l}\text { Powase aahi: "Apwiya } \\
\text { yooreelihe mwanaka! Osivela waa } \\
\text { woororomeleya [ד]ד] wuuwu onnapwaha } \\
\text { woopacerya waacharaka apwiyamwanaa, } \\
\text { ohichunaka otheliwa ni mmiravo nari } \\
\text { amuhakhu nari oohaawa." }\end{array}$ \\
\hline
\end{tabular}

Table 3: Text of Ruth 3:10 in Hebrew, Greek and Lomwe

In 3:10, Boaz mentioned Ruth's חסד to her mother-in-law when he blessed her: "May you be blessed by the LORD, my daughter; you have made this last kindness [חסד] greater than the first, in that you have not gone after young men, whether poor or rich". He told Ruth that her new demonstration of חסד is greater than the earlier חסד that he praised her for namely her care for her mother-in-law. Ruth was willing to abandon the secure environment of the father's house to follow her mother-in-law:

\footnotetext{
28 In this passage, the Makhuwa translators have also opted for ikharari as the most suitable term for חסד. They claim that the verse highlights the important aspect of care and protection which Boaz provided for both Ruth and Naomi.

29 Again, the Greek text does not play any significant role in the discussion of 3:10 but it is shown in the table in order to present the text consistently.
} 
Where you go I will go, and where you stay I will stay. Your people will be my people and your God my God. Where you die I will die, and there I will be buried. May the LORD deal with me, be it ever so severely, if anything but death separates you and me (Ruth 1:16-17).

This declaration shows the commitment and determination of Ruth to stay with Naomi regardless of the circumstances. Such devotion must be read in conjunction with Ruth 3:10 because both verses emphasize Ruth's self-sacrifice and loyalty toward Naomi. Her selfsacrifice and loyalty ensured that the name of Elimelech was not cut off from among his family or clan (Ruth 4:10). It should be noted that if Ruth had decided to remain in Moab, the family of Elimelech would have ceased to be. His family line would have died out among the people of Israel. Thus, Ruth's act did not merely preserve a family line, but it ensured the continuation of a family line within Israel's covenantal framework of the 'people of God'.

The Lomwe society is agrarian and family relationships are structured on the principle of nihimo (clan) through which an all-encompassing family care unit is formed. As noted, the term nihimo does not necessarily refer to a 'closed group', but denotes a group of siblings which may include all the people who belong to a given extended family. Hence, the concept of nihimo is a central feature of kinship organization that is constituted not only by members of the same clan but also by those of other clans who are joined through marriage. As in the Lomwe society, marriage in ancient Israel created a bond between families of different clans. ${ }^{30}$ However, as a matriarchal society, the Lomwe trace their descent through the lineage of mothers while the ancient Israelites traced their descent through the lineage of fathers.

Having established the socio-cultural world of both the Lomwe and the ancient Israelites, it is imperative to consider the translation of חסד as osivela waya woororomeleya in Lomwe. The Lomwe translators have chosen this phrase as the most suitable translation for חסד because it emphasizes the aspect of marriage relationship. After Naomi told her two daughters-in-law to go back to their mothers' houses, Ruth refused and continued to follow Naomi of her own free will. If she was not under any obligation to stay, why did Ruth decide to stay with her mother-in-law? One could argue here that the willingness to stay with her mother-in-law is a result of her exceptional family loyalty (and not so much of any action). This particular verse communicates that showing חסד implies the attitude of loyalty. Linked with the notion of loyalty is the idea of self-sacrifice. Boaz's reference to Ruth's חסד in 3:10 is recognition of her self-sacrifice, the willingness to remain a widow and to relinquish the privileges of a married life among her own people (e.g. honour, prestige, respect and self-esteem). Hence, this verse highlights the exceptional attitude of Ruth.

Since the expression osivela waya woororomeleya (lit. love his/her faithful, i.e. his/her faithful love) which is used by the Lomwe translators does not convey this particular connotation of 'attitude/disposition' in 3:10, oreera murima (lit. good heart, i.e. [a person]

30 Foster (2008) rejects the idea that marriage creates a bond between families of different clans (mahimo, plural) in Lomwe. 
of good heart) is proposed as an alternative rendering of חסד in Lomwe because it best describes Ruth's disposition.

Although empirical research was conducted among the Lomwe, the choice of oreera murima for 3:10 was not entirely informed by that research. The reason was that whenever this verse was read in both the PV and CV to the Lomwe respondents in the course of the fieldwork, most of them asked that it be repeated before they chose their preferred translation. In the end, the majority chose the PV's osivela waya woororomeleya but the uncertainty of the people when they made their choice convinced the researcher not to rely on their responses. They were equally uncertain about the expression oreera murima in the $\mathrm{CV}$ and asked that that version be read repeatedly.

Due to the uncertainty among the Lomwe interviewees, I decided to crosscheck this case with the Bible translators. The Lomwe translators were first consulted by means of questionnaires $^{31}$ and they maintained the choice of osivela waya woororomeleya. Their preference was, however, determined by their translation decision to keep this expression in all three cases in Ruth. Subsequently, the Makhuwa Bible translators ${ }^{32}$ were also interviewed for further assistance in determining a suitable translation of חסד in Lomwe. They opted for oreera murima in 3:10 (which is the same expression used in the CV) because according to them, it communicates the additional feature of 'attitude'.

It was decided therefore that the expression oreera murima be suggested as a translation alternative in the PV on account of two reasons: (i) The expression oreera murima expresses the attitude/disposition involved in this verse more clearly than osivela waya woororomeleya. Therefore, it is more in line with the CFR model proposed above. (ii) The expression oreera murima also provides the opportunity to distinguish the usage in 3:10 from 1:8 and 2:20. In those cases, it was suggested that the word ikharari (which carries the element of 'action') be used. The recommended expression oreera murima in 3:10 takes into account the element of 'attitude' which is more appropriate here in terms of the CFR model.

The choice is made being well aware of the fact that the expression oreera murima created an equal amount of uncertainty amongst the Lomwe interviewees. However, it is proposed here because it is more in line with the CFR model that is used in this study something that cannot be said of the alternative expression osivela waya woororomeleya.

\section{Conclusion}

In this article, I have evaluated the suitability of the terms osivela/woororomeleya and ikharari in relation to other Lomwe terms which could convey the conceptual complexity denoted by חסד. To evaluate the suitability of these terms as the translation of חסד into Lomwe, the CFR model was applied. This model offers a multifaceted method for understanding the meaning of חסד in Ruth 1:8, 2:20 and 3:10. Since osivela waya

32 Since the Lomwe share the same culture with and belong to the same language group as the Makhuwa, the Makhuwa translators were then interviewed in order to crosscheck whether any other alternative term would arise (see Alfredo 2010:190). 
woororomeleya does not do justice to the meaning of חסד in these three passages, I have proposed that the expressions ikharari (1:8 and 2:20) and oreera murima (3:10) be considered exegetically and socio-culturally appropriate for translation.

\section{BIBLIOGRAPHY}

Alfredo, J 2010. "חסד and Ikharari: The Book of Ruth from a Lomwe Perspective". DTh. Dissertation. Stellenbosch: Stellenbosch University.

Alfredo, J 2012. Translating Biblical Words: A Case Study of the Hebrew Word, חסד. Scriptura, Vol. 109:1-15.

Assane, A 2002. Factores que Influenciam a Formação e Funcionamento dos Grupos de Componeses Baseados na Ajuda Mutual. Licenciatura. Maputo: Universidade Eduardo Mondlane (UEM).

De Blois, R 2006. Semantic Dictionary of Biblical Hebrew (SDBH). Reading: United Bible Societies.

Fensham, FC 1962. Widow, Orphan, and the Poor in Ancient Near Eastern Legal and Wisdom Literature. Journal of Near Eastern Studies, 21(2):129-139.

Floor, S 2005. "Toward a New Curriculum for Bible Translator Training in Mozambique". Paper Read at the Joint Conference of OTSSA on Bible Interpretation and Translation held at the University of KwaZulu-Natal in Pietermaritzburg, September 2005.

Foster, SJ 2008. An Experiment in Bible Translation as Transcultural Communication: The Translation of בּרית 'Covenant' into Lomwe, with a Focus on Leviticus 26. Stellenbosch: SUN Media Press.

Kitoko-Nsiku, E 2007. Dogs' Languages or People's Language? The Return of Bantu Languages to Primary Schools in Mozambique. Current Issues in Language Planning, 8(2):258-282.

Meyers, C 1978. Roots of Restriction: Women in Early Israel. Biblical Archaeologist, 41:91-103.

Meyers, C 1991. 'To Mother's House': Considering a Counterpart to the Israelite Be'ab, in D. Jobling et al. (eds.). The Bible and the Politics of Exegesis. Cleveland: Pilgrim.

Nida, EA and Taber, CR 1969. The Theory and Practice of Translation. Leiden: Brill.

Sociedade Biblica em Moçambique (SBM). 1999. Mapacereryo. Maputo: Muteko wa wuuka wa Piipiliya oMosampike.

Sociedade Biblica em Moçambique (SBM) 2008. Ruute. Maputo: Sociedade Biblica em Moçambique.

Usue, E 2006. Theological Perspectives on the Concept of 'Yahweh's People' in Ezra and Nehemiah during the Early Post-Exilic Period (539-350 BC) - Part II. OTE, 19(1):205-215. 


$$
\text { http://scriptura.journals.ac.za }
$$

Wilt, T 2007. Translating Bibles in Central Africa: Some Recurring Questions, in AK

Mukenge et al. (eds). Cultural Readings of the Bible in Africa. Yaounde: Editions CLE, 119-139.

Yorke, GLOR 2004. Bible Translation in Lusophone Africa: The Case of Mozambique, in GLOR Yorke \& PM Renju (eds.). Bible Translation and African Languages.

Nairobi: Acton, 59-69. 